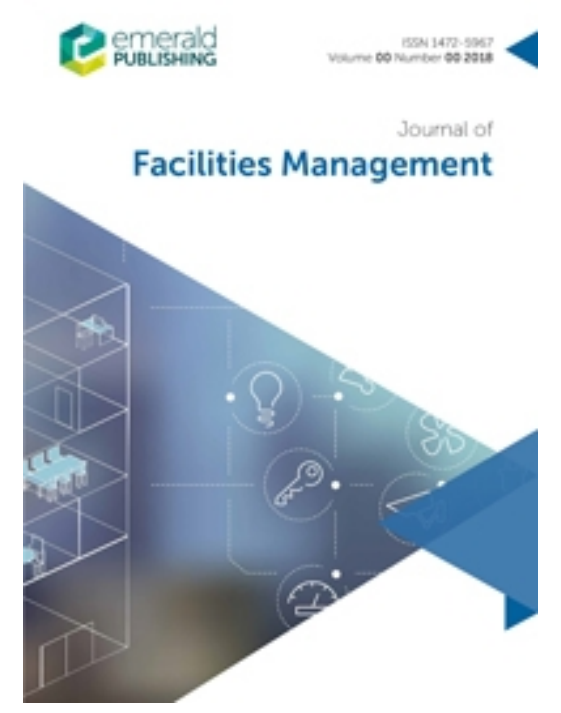

\title{
Post occupancy evaluation of thermal comfort and indoor air quality of office spaces in a tropical green campus building
}

\begin{tabular}{|r|l|}
\hline Journal: & Journal of Facilities Management \\
\hline Manuscript ID & JFM-12-2020-0092.R1 \\
\hline Manuscript Type: & Research Paper \\
\hline Keywords: & $\begin{array}{l}\text { Thermal comfort, Indoor air quality (IAQ), Post occupancy evaluation } \\
\text { (POE), Green campus building, Neutral temperature, open-plan office }\end{array}$ \\
\hline
\end{tabular}

\section{SCHOLARONE ${ }^{\text {M }}$ Manuscripts}


Abstract

Purpose

As suggested in many previous studies, good thermal comfort and indoor air quality (IAQ) played a significant role in ensuring human comfort, health and productivity in buildings. Hence, this study aims to evaluate the thermal comfort and IAQ conditions of open-plan office areas within a green campus building through a post occupancy evaluation (POE).

Design/ methodology/ approach

Using the field measurement method, environmental dataloggers were positioned at three office areas during office hours to measure the levels of thermal comfort parameters, $\mathrm{CO}_{2}$ concentrations and the supply air rates. At the same time, questionnaires were distributed to the available office staff to obtain their perception of the indoor environment. The data collected were then compared to the recommended environmental comfort ranges and were used to calculate the thermal comfort indices.

Findings

Results show that the physical parameters were generally within acceptable ranges of a local guideline except for the air velocity. The neutral temperature based on the actual mean vote (AMV) at these areas was $23.9^{\circ} \mathrm{C}$, which is slightly lower than the predicted thermal neutrality of $25.2^{\circ} \mathrm{C}$. From the surveyed findings, about $81 \%$ of the occupants found their thermal environment comfortable with high adaptation rates. A preference for cooler environments was found among the workers. Meanwhile, the air quality was perceived to be clean by a majority of the respondents, and the mean ventilation rate per person was identified to be sufficient.

Research limitations/ implications

This study focused on the thermal environment and air quality of selected office spaces only. More work should be carried out in other regularly occupied workplaces and study areas of the educational building to allow a more thorough analysis of the indoor air conditions.

Practical implications

This paper highlights on the thermal comfort and air quality conditions of the air-conditioned office spaces in a green-certified educational building and is intended to assist the building services engineers in effective air conditioning control. The findings reported are useful for thermal comfort, IAQ and subsequently energy efficiency improvements in such building type where adjustments on the air supply rate and fresh air intake can be made according to the actual requirements. This study will be extended to other green campus spaces for a more exhaustive analysis of the indoor environment.

Originality/ value

There is limited information pertaining to the environmental comfort levels in offices of a green campus in the tropics. This study is therefore one of the earliest attempts to directly explore the thermal comfort and IAQ conditions in such workplace using on-site physical measurement and questionnaire survey. 
Keywords: Thermal comfort, indoor air quality (IAQ), open-plan office, green campus building, post occupancy evaluation (POE), neutral temperature

\section{Introduction}

Due to the recognition of the importance of good indoor environmental quality (IEQ) on occupant safety, productivity and health, studies which focused on the analysis of thermal comfort and air quality conditions have been directed towards different building types, most notably in commercial complexes (Gallardo et al., 2016; Gutierrez-Aliaga \& Williams, 2016; Langevin et al., 2015; Lakeridou et al., 2012; Smith et al., 2017), Institutional buildings (El-Darwish \& El-Gendy, 2018; Khajehzadeh and Vale, 2016; Mihai \& lordache, 2016) and residential homes (Wang et al., 2015; Rijal et al., 2015; Li et al., 2018). In recent years, with the increasing awareness on the negative impacts of poorly designed and maintained buildings to the environment, various green building tools have been introduced to encourage the adoption of new design and refurbishment strategies by the building professionals. These methods have been formulated to suit the unique climatic conditions and local practices. For instance, several green building rating tools have been developed in Malaysia and widely used by the architects and building engineers in designing new buildings, and also allow them to retrofit the existing ones to make them achieving the status of sustainable buildings.

Post occupancy evaluation (POE) is among the most commonly used methods for assessing indoor environment and occupant comfort perception. This evaluation method usually encompasses several qualitative and quantitative techniques which include building environmental monitoring using electronic devices, questionnaire survey, interviews and others. It was proposed that POE is very useful in facilitating the integrations of many building design aspects and has an essential role in encouraging sustainability development and improving occupant satisfaction (Meir et al., 2009; Hwang and Kim, 2013; Toyin Sawyerr and Yusof, 2013). For thermal comfort assessments, the results obtained from POE have been reported and often compared to the comfort ranges prescribed in building standards, such as ASHRAE Standard 55 (2017). Wang et al. (2015) studied the adaptive behaviour of occupants in green residential buildings in China by applying both POE and software simulation. The relationship between adaptive thermal comfort and energy use was highlighted. A previous work which analysed the IEQ conditions in affordable houses with residents' satisfaction level found that air movement and ventilation rate as among the most essential IEQ parameters (Kamaruzzaman and Azmal, 2019). To identify the effect of raised air temperature towards occupant thermal comfort, Lakeridou et al. (2012) compared the thermal comfort conditions at two floors of a UK office building with different cooling set-points during summer via the POE approach. The findings revealed that occupants at the intervention floor with increased temperature had a similar satisfaction level as those at the cooler one, though some respondents reported that they felt warmer. It was also suggested that if coupled with instrumental measurement, the POE can provide a better description of actual occupant thermal comfort and overall building performance (Deuble and de Dear, 2014). A study which applied the adaptive comfort approach has suggested that the use of adaptive temperature limits could not only improve thermal comfort, but also saves energy (Kramer et al., 2018). Using questionnaire survey with 6-point likert-type scale, Sant'Anna et al. (2018) found that occupants of green buildings had higher satisfaction levels and better eco-friendly attitude. Driza and Park (2014) carried out questionnaire survey together with interview sessions to investigate user's 
satisfaction and concern in LEED-certified academic facilities and the findings proposed the need for an integration between POE and green assessment tools to improve sustainable development.

As for studies where air quality in buildings were concern, an IAQ assessment carried out in Norwegian and British offices reported that the employees working in cellular offices experienced less buildingrelated symptoms compared to those sitting at open plan offices (Shahzad et al., 2016), while the statistical analysis of a longitudinal survey on occupational comfort perceptions proposed that occupants' satisfaction level of the thermal environment and air quality could have impacted occupant work performance (Bunn and Marjanovic-Halburd, 2017). With the use of environmental sensors and building modelling techniques, the association between $\mathrm{CO}_{2}$ level in an open-plan office space and workplace comfortableness was established in a recent work (Roskams and Hayes, 2019) and the realtime monitoring of this air contaminant is possible nowadays with the advancement in web-based technologies (Marques et al., 2019). The occupants' number, sitting position, duration of occupancy and the location of the ventilation systems were found to be affecting the indoor $\mathrm{CO}_{2}$ concentrations (Mahyuddin et al., 2014). Although these studies have been directed towards the analysis of thermal comfort in buildings, the scantiness of information on of these two environmental parameters in the sustainable buildings in the tropics, especially those built for academic purposes requires more work to be done. The outcomes are not only important to address the issue of heavy dependency on the use of air-conditioning systems but also to sustain workers' wellbeing, productivity and comfort. Understanding the actual perception of workers in such building type is important to balance between the requirement for thermal comfort and energy use.

This paper attempts to analyse the thermal environment and indoor air conditions of three office spaces in a green campus through a POE which utilised both questionnaire survey and on-site measurement using calibrated instrumentation. Throughout the field survey, the thermal and air quality perceptions of the occupants were recorded, and the neutral temperature of the office spaces was determined based on the actual mean vote (AMV), PMV and the calculated operative temperature.

\section{Case study}

The selected campus building was designed to fulfil the criteria of a local green building tool where green technologies and advanced architectural features are extensively used. It was equipped with a computerised building management system (BMS) to monitor, manage and maintain the mechanical and electrical equipment used in the campus. For cooling and dehumidification of indoor air, a centralised air-conditioning system was used and the return air temperature was set at $23.5^{\circ} \mathrm{C}$ for energy efficiency purpose. The air quality in the building was monitored using the carbon dioxide $\left(\mathrm{CO}_{2}\right)$ sensors, which were installed at the air-conditioned areas. Circulation of indoor air was made for most of the time to conserve energy, but the fresh air intake would be automatically activated when the $\mathrm{CO}_{2}$ level was above the set-point of $800 \mathrm{ppm}$. Natural ventilation strategies were applied at the partially open spaces, such as the waiting areas to reduce air-conditioning load.

Other than that, occupancy sensors were used to determine the number of users at each office room. To prevent glare problem and reduce radiant heat emissions, the window glass panel was made of low-emissivity glazing. At the main administrative building, automated blind curtains were also 
installed to prevent visual discomfort primarily caused by the penetration of direct sunlight at this location besides reducing the solar heat gain during office hours (Lau, 2019). These locations were selected because they possess the typical features of non-residential green buildings.

\section{Material and methods}

\subsection{Field measurement}

The POE survey was undertaken in October 2019 at three open-plan office areas within the administrative and academic blocks of the campus. No measurement was made at the executive offices and the ancillary spaces due to the limited number of dataloggers. Before the actual measurement, a pilot test was done in $24^{\text {th }}$ August 2019 to find out the suitable measuring spots and to ensure that the dataloggers functioned as intended. Following the requirement for physical measurement for seated positions (ASHRAE, 2017), a thermal comfort datalogger (Delta Ohm HD32.3) was positioned at about $0.6 \mathrm{~m}$ above floor level and near to the occupied workstations to record air temperature, relative humidity, globe temperature, air velocity and other indoor thermal environmental factors at 5-minute intervals throughout the field survey. The measurement was conducted from 9am to $5 \mathrm{pm}$ at each day of the survey. As illustrated in Figure 1, the measuring points were selected to characterise the actual thermal comfort conditions during work time. This datalogger was connected with three sensors - Omnidirectional hot wire anemometer, air temperature/ humidity probe and globe temperature probe. At the same time, a handheld datalogging $\mathrm{CO} / \mathrm{CO}_{2}$ meter was used to detect the $\mathrm{CO}_{2}$ concentration level in the office spaces and the supply air flow rate was measured using an anemometer with telescoping probe. The descriptions of the experimental set-up and sensor probes used are presented in Table 1.

Table 1: Information of the experimental set-up and sensor probes

\begin{tabular}{|c|c|c|c|c|}
\hline Parameter & $\begin{array}{l}\text { Equipment/ } \\
\text { sensor model }\end{array}$ & $\begin{array}{l}\text { Measuring } \\
\text { range }\end{array}$ & Resolution & Location \\
\hline Air temperature $\left(\mathrm{T}_{\mathrm{a}}\right)$ & HP3217.2R & -40 to $100^{\circ} \mathrm{C}$ & $0.1^{\circ} \mathrm{C}$ & $0.6 \mathrm{~m}$ above floor \\
\hline Air velocity $(\mathrm{m} / \mathrm{s})$ & AP3203.2 & 0.1 to $5 \mathrm{~m} / \mathrm{s}$ & $0.01 \mathrm{~m} / \mathrm{s}$ & $0.6 \mathrm{~m}$ above floor \\
\hline $\begin{array}{l}\text { Mean radiant } \\
\text { temperature }\left(T_{M R T}\right)\end{array}$ & TP3276.2 & $-10 \div 100^{\circ} \mathrm{C}$ & $0.1^{\circ} \mathrm{C}$ & $0.6 \mathrm{~m}$ above floor \\
\hline Relative humidity $(\mathrm{RH})$ & HP3217.2R & 0 to $100 \% \mathrm{RH}$ & $\begin{array}{l} \pm 1.5 \%(0- \\
90 \% \mathrm{RH}) / \\
\pm 2 \%(90- \\
100 \% \mathrm{RH})\end{array}$ & $0.6 \mathrm{~m}$ above floor \\
\hline $\mathrm{CO}_{2}$ & Extech CO260 & $\begin{array}{l}0 \text { to } \\
9,999 \mathrm{ppm}\end{array}$ & $1 \mathrm{ppm}$ & $\begin{array}{l}\text { Air diffusers, } \\
\text { grilles and desk } \\
\text { level }(0.75 \mathrm{~m} \text { above } \\
\text { floor) }\end{array}$ \\
\hline $\begin{array}{l}\text { Air velocity }(\mathrm{m} / \mathrm{s}) \text { at } \\
\text { diffusers }\end{array}$ & Extech AN340 & 0.5 to $20 \mathrm{~m} / \mathrm{s}$ & $0.1 \mathrm{~m} / \mathrm{s}$ & Supply air diffusers \\
\hline
\end{tabular}

The ventilation rate per occupant for each office space was calculated using the $\mathrm{ACH}$ values and the occupation density value specified in CIBSE (2008).

3.2 Occupant perception survey 
There were 59 workers ( 47 administrative and 12 academic) in the building under study. Only the office staff who had remained seated in their workstations for at least 15 minutes were invited as survey respondents, which made the total number of respondents 36 people. The aim of the study was explained to the staff prior to the survey and each of them were then given a set of questionnaire form. There were four sections in this two-page form, which are (A) demographic information, (B) thermal comfort and air quality sensation, (C) thermal environment acceptability, preference and adaptation and (D) perception on air quality and overall comfort conditions. Standardised selfassessed clothing level (thermal resistance value) and activity level checklist were included in the first section of the questionnaire as the information are essential for the Predicted Mean Vote (PMV) and Predicted Percentage Dissatisfied (PPD) estimations. For the second and third sections, the ASHRAE 7point scale was used to quantify the respondents' reception of their thermal surroundings, which included their level of adaptation. Meanwhile, the IAQ was evaluated based on the impressions of air cleanliness (free from dust and smell). The questionnaire completion time and location of the survey were recorded at the top-right corner of the form.

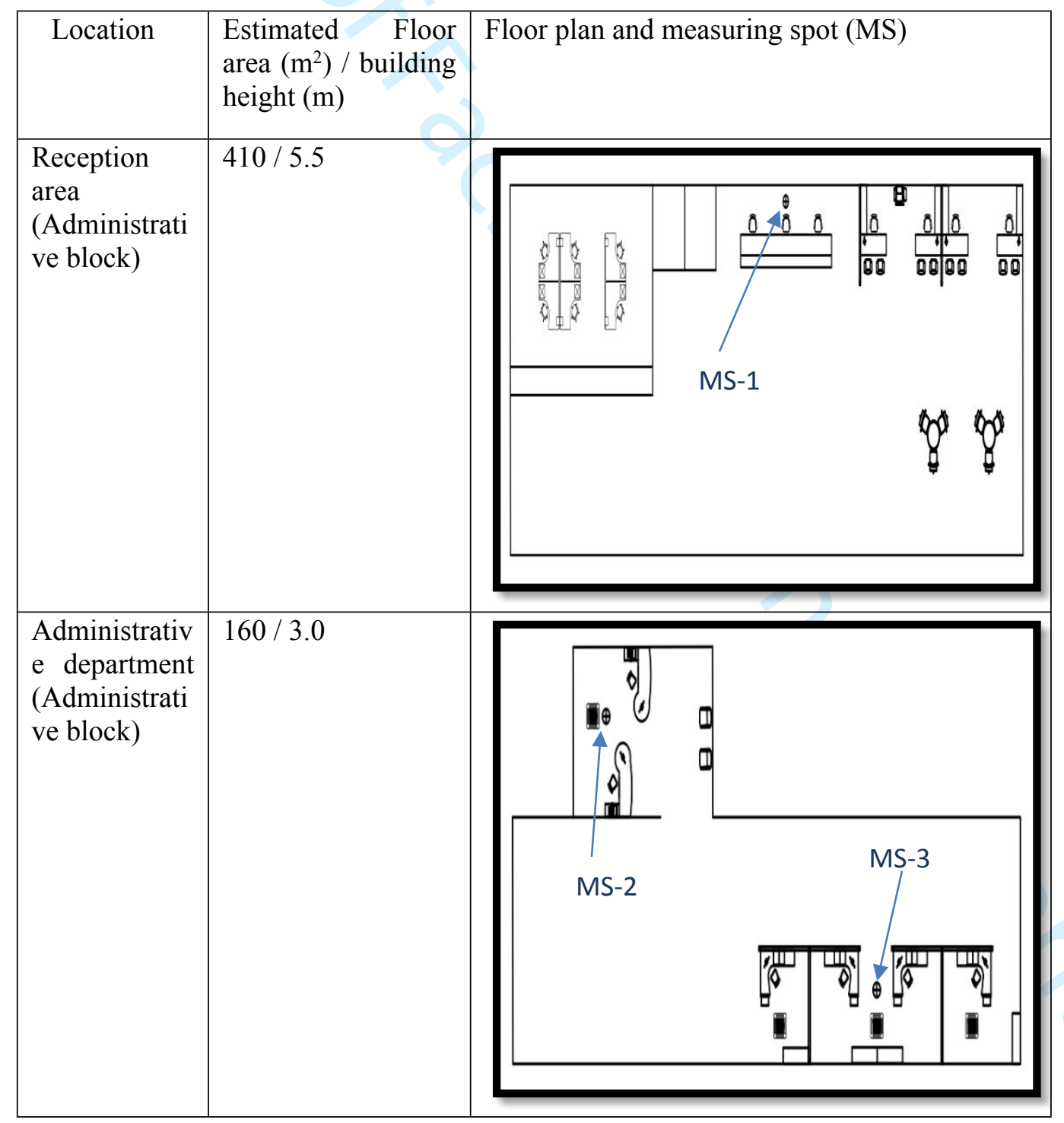




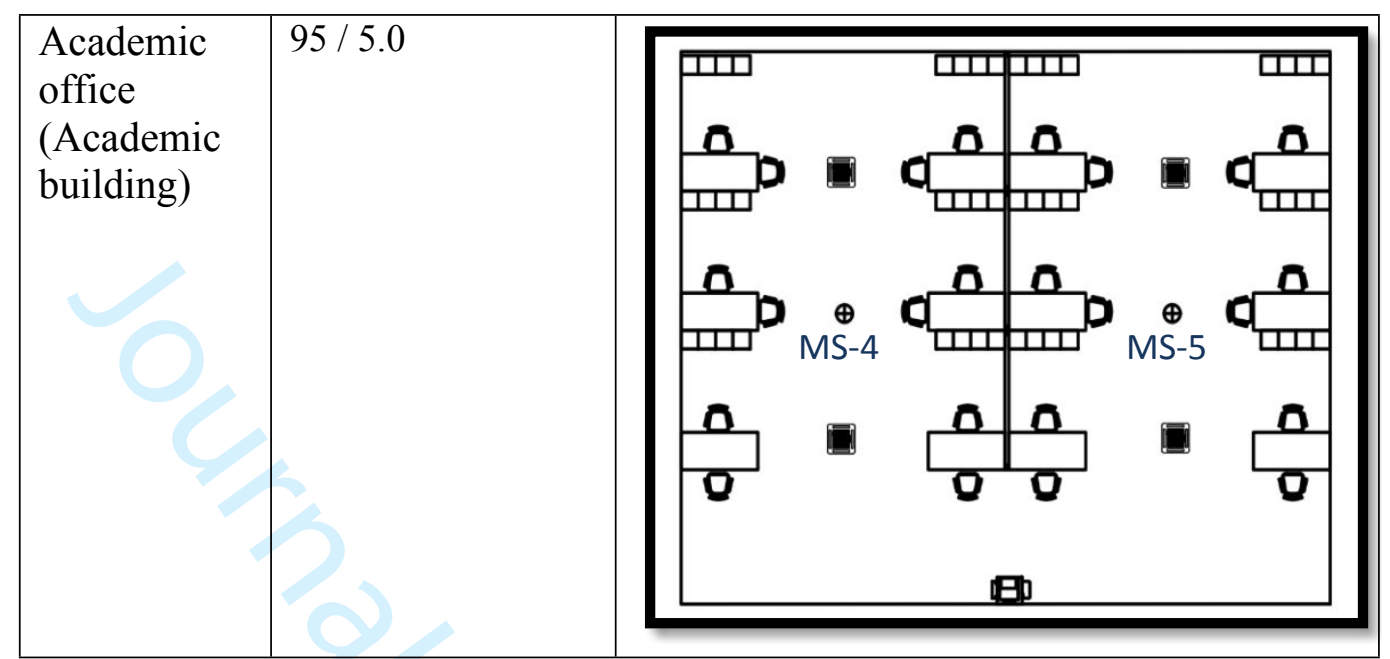

Figure 1: Building information and measuring points selected for POE

\section{Results}

The thermal environmental factors, supply air speed and $\mathrm{CO}_{2}$ level of three office spaces in a green campus building were measured while the occupant thermal comfort and IAQ perceptions were recorded concurrently. The thermal neutrality of the offices was determined using the calculated AMV, PMV and operative temperature. The $\mathrm{ACH}$ and ventilation rate per occupant were also estimated.

\subsection{Thermal environmental parameters}

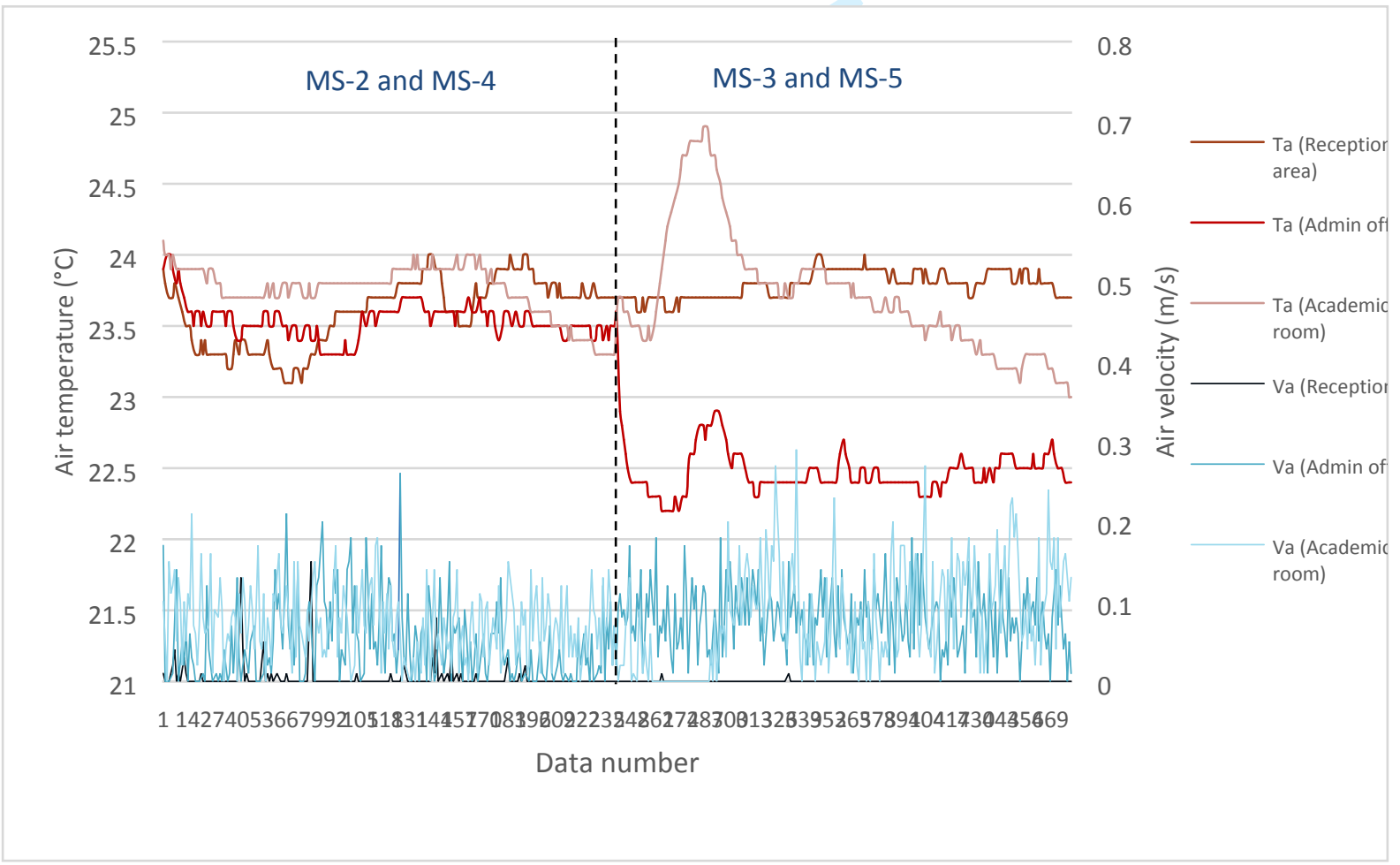

Figure 2: Air temperature and velocity profiles 
DOSH (2010) specified that the air temperature, $\mathrm{RH}$ and air movement of a non-residential indoor space or enclosed environment should be within 23 to $26^{\circ} \mathrm{C}, 40$ to $70 \% \mathrm{RH}$ and 0.15 to $0.5 \mathrm{~m} / \mathrm{s}$, respectively. It was documented that the room temperature could have significant impact on workers' productivity, where an increase of $1^{\circ} \mathrm{C}$ from the occupants' neutral temperature could result in a $9.2 \%$ decrease in mean productivity level (Clements-Croome, 2001). Using air-conditioners, the two controllable thermal comfort parameters are the air temperature and air movement rate. Studies on thermal comfort in the tropical regions had identified that these two parameters are more dominant in defining overall comfort of the occupants, and high humidity levels were often found to be tolerable (Kwong et al., 2011; Lu et al., 2018; He at al., 2016). The indoor air temperature and velocity profiles of the studied building are shown in Figure 2, where 480 readings were taken at each location. The air temperature at the three office spaces was controlled within the range of $22.2^{\circ} \mathrm{C}$ to $24.9^{\circ} \mathrm{C}$, while the air velocity varied from 0 (below detection limit) to $0.29 \mathrm{~m} / \mathrm{s}$. The highest temperature fluctuation was found at the administrative office, where the temperature measured at MS-2 was slightly higher than that of MS-3. As for the movement of air, the location with the highest variation was in the academic room (MS-5).

Table 2: Mean values of thermal comfort factors

\begin{tabular}{lcccccccc}
\hline Location & $\mathrm{MS}$ & $\mathrm{T}_{\mathrm{g}}\left({ }^{\circ} \mathrm{C}\right)$ & $\mathrm{T}_{\mathrm{a}}\left({ }^{\circ} \mathrm{C}\right)$ & $\mathrm{T}_{\mathrm{r}}\left({ }^{\circ} \mathrm{C}\right)$ & $\mathrm{RH}(\%)$ & $\mathrm{V}_{\mathrm{a}}(\mathrm{m} / \mathrm{s})$ & $\mathrm{PMV}$ & $\mathrm{PPD}$ \\
\hline Reception area & 1 & 23.3 & 23.7 & 23.3 & 58.5 & 0.00 & -0.73 & 16.23 \\
& & & & & & $(0.002)^{*}$ & & \\
Administrative & 2 & 23.4 & 23.5 & 23.3 & 58.1 & 0.05 & -0.78 & 18.02 \\
office & 3 & 22.4 & 22.5 & 22.3 & 61.3 & 0.08 & -1.15 & 33.28 \\
Academic room & 4 & 23.6 & 23.8 & 23.6 & 77.4 & 0.07 & -0.56 & 11.72 \\
& 5 & 23.6 & 23.7 & 23.5 & 71.1 & 0.08 & -0.66 & 15.42 \\
\hline
\end{tabular}

*Sometimes below detection limit

The mean values of the measured thermal comfort parameters and the PMV-PPD indices are tabulated in Table 2. It can be observed that only there is only slight variation between the mean air temperatures at the office spaces. The lowest air temperature was measured at MS- 3 with a mean value of $23.5^{\circ} \mathrm{C}$, which was part of the administrative office. The warmest location appears to be at the academic room, where a mean air temperature of $23.8^{\circ} \mathrm{C}$ was recorded. As for the air movement, the reception area was the stuffiest place where air movement was sometimes not detected during the survey. The air velocity at this space was within 0 to $0.15 \mathrm{~m} / \mathrm{s}$. Meanwhile, the air velocity at the administrative office fluctuated between 0 and $0.26 \mathrm{~m} / \mathrm{s}$, and an overall average value of $0.06 \mathrm{~m} / \mathrm{s}$ was obtained. As for the academic room, a mean temperature of $23.7^{\circ} \mathrm{C}$ was obtained, while the air velocity at this space ranged from 0 to $0.29 \mathrm{~m} / \mathrm{s}$ with an average $0.08 \mathrm{~m} / \mathrm{s}$. The RH values in the academic room were noticeably higher than the two other areas and peaked at $79 \%$.

The calculation of the PMV-PPD indices for thermal comfort analysis was automatically completed by the integrated software of the environmental datalogger, which adheres to the ISO 7730: 2005 requirements. As observed during the pilot survey, the occupants' level of clothing insulation was determined as 0.55 clo (light clothing level for both men and women) which is normal for working adults in the tropics and their activity level at 1.0 MET (low metabolic rate) or $58.15 \mathrm{~W} / \mathrm{m}^{2}$ which represents sitting and writing activities. These indices have been applied in various thermal comfort 
studies and were found to be suitable for the evaluation of working environment with moderate microclimate such as offices. Most of the occupants working in this campus building were predicted to find their thermal environment "neutral", while a few of them at the administrative office would feel "slightly cool" as the lowest PMV of -1.15 was found at MS-3. It was also predicted at this point that more than $30 \%$ of the workers would be thermally uncomfortable.

\subsection{Questionnaire survey}

The thermal sensation, preference and adaptation levels of the occupants were obtained through the filled questionnaires. From Table 3 , none of the votes were placed on the warm side $(+2,+3)$ of the thermal sensation scale. Besides, it can be seen that about $81 \%$ of the respondents placed their votes within slightly cool and slightly warm, whereas 7 occupants stated that they were feeling either cool or cold. Most of the cool sensation ratings were received at the administrative office. On the other hand, a significant proportion of the receptionists and front desk workers experienced mild warm temperature feeling. A total mean TSV of -0.68 was obtained, which demonstrated that the overall thermal sensation to be tilted towards the cooler side of the scale, albeit slightly.

Table 3: Thermal sensation vote (TSV)

\begin{tabular}{|c|c|c|c|c|c|c|c|c|c|}
\hline \multirow[t]{2}{*}{ Location } & \multirow{2}{*}{$\begin{array}{l}\text { Number } \\
\text { of } \\
\text { subjects }\end{array}$} & \multicolumn{7}{|c|}{ TSV on ASHRAE 7-point scale } & \multirow[t]{2}{*}{ Mean TSV } \\
\hline & & $\begin{array}{c}\text { Cold } \\
-3\end{array}$ & $\begin{array}{c}\text { Cool } \\
-2\end{array}$ & $\begin{array}{c}\text { Slightly } \\
\text { cool } \\
-1\end{array}$ & $\begin{array}{c}\text { Neutral } \\
0\end{array}$ & $\begin{array}{c}\text { Slightly } \\
\text { warm } \\
+1\end{array}$ & $\begin{array}{c}\text { Warm } \\
+2\end{array}$ & $\begin{array}{c}\text { Hot } \\
+3\end{array}$ & \\
\hline Reception area & 14 & 0 & 2 & 6 & 1 & 5 & 0 & 0 & -0.36 \\
\hline Administration & 5 & 1 & 1 & 2 & 1 & 0 & 0 & 0 & -1.40 \\
\hline office & 5 & 1 & 1 & 3 & 0 & 0 & 0 & 0 & -1.60 \\
\hline Academic & 6 & 0 & 1 & 1 & 3 & 1 & 0 & 0 & -0.33 \\
\hline room & 6 & 0 & 0 & 3 & 2 & 1 & 0 & 0 & -0.33 \\
\hline 36 & 2 & 5 & 16 & 7 & 7 & 0 & 0 & & \\
\hline
\end{tabular}

Table 4: Thermal and air movement preferences

\begin{tabular}{lccccc}
\hline \multirow{2}{*}{ Location } & \multicolumn{3}{c}{ Air Temperature } & \multicolumn{2}{c}{ Air Movement } \\
\cline { 2 - 6 } & Cooler & $\begin{array}{c}\text { No } \\
\text { Change }\end{array}$ & Warmer & $\begin{array}{c}\text { No } \\
\text { Change }\end{array}$ & More \\
\hline Reception area & 5 & 7 & 2 & 11 & 3 \\
Administration office & $(35.7)$ & $(50.0)$ & $(14.3)$ & $(78.6)$ & $(21.4)$ \\
Academic room & 3 & 6 & 1 & 7 & 3 \\
& $(30.0)$ & $(60.0)$ & $(10.0)$ & $(70.0)$ & $(30.0)$ \\
& 3 & 8 & 1 & 6 & 6 \\
& $(25.0)$ & $(66.7)$ & $(8.3)$ & $(50.0)$ & $(50.0)$ \\
\hline
\end{tabular}

The preference of the occupants towards changing the air temperature and velocity conditions within the offices are tabulated in Table 4 . It can be observed that $58 \%$ of them preferred no changes are needed to the existing thermal environment, while a substantial fraction of $31 \%$ wanted their environment to be cooler. As for the air movement, no votes were collected for the need to reduce air velocity. Similar to the thermal preference, $67 \%$ of the occupants favoured the current air velocity and the remaining ones wanted higher air movement rates. It was also found that respondents who wished to have a cooler office space also preferred an increase of the air movement rate.

The adaptive behaviour of the occupants was analysed using the 7-point behavioural scale and the findings are shown in Table 5. 80\% of the occupants mentioned that they had at least slightly adapted 
to their immediate thermal environment and a mean adaptive score of 1.17 was obtained. $17 \%$ of them were not sure of whether they had adapted and only one (3\%) respondent felt not adapted. The highest adaptation rate was recorded at the administrative office at which $90 \%$ of the staff claimed to be highly adapted. Meanwhile, the academic staff reported the lowest adaptive level where only $67 \%$ found themselves adapted to their workplace thermal environment.

Table 5: Occupant adaptation level

\begin{tabular}{|c|c|c|c|c|c|c|c|}
\hline \multirow{2}{*}{ Location } & \multicolumn{7}{|c|}{ Adaptation level (low to high) } \\
\hline & $\begin{array}{c}-3 \\
\text { (slightly) }\end{array}$ & -2 & -1 & 0 & 1 & 2 & $\begin{array}{c}3 \\
\text { (fully) }\end{array}$ \\
\hline Reception area & $\begin{array}{c}0 \\
(0.0) \\
\end{array}$ & $\begin{array}{c}0 \\
(0.0) \\
\end{array}$ & $\begin{array}{c}1 \\
(7.1) \\
\end{array}$ & $\begin{array}{c}3 \\
(21.4) \\
\end{array}$ & $\begin{array}{c}2 \\
(14.3) \\
\end{array}$ & $\begin{array}{c}6 \\
(42.9) \\
\end{array}$ & $\begin{array}{c}0 \\
(0.0) \\
\end{array}$ \\
\hline Administration office & $\begin{array}{c}0 \\
(0.0) \\
\end{array}$ & $\begin{array}{c}0 \\
(0.0) \\
\end{array}$ & $\begin{array}{c}0 \\
(0.0) \\
\end{array}$ & $\begin{array}{c}0 \\
(0.0)\end{array}$ & $\begin{array}{c}0 \\
(0.0) \\
\end{array}$ & $\begin{array}{c}6 \\
(60.0) \\
\end{array}$ & $\begin{array}{c}3 \\
(30.0)\end{array}$ \\
\hline Academic room & $\begin{array}{c}0 \\
(0.0)\end{array}$ & $\begin{array}{c}0 \\
(0.0)\end{array}$ & $\begin{array}{c}1 \\
(8.3)\end{array}$ & $\begin{array}{c}1 \\
(8.3)\end{array}$ & $\begin{array}{c}3 \\
(25.0)\end{array}$ & $\begin{array}{c}3 \\
(25.0)\end{array}$ & $\begin{array}{c}0 \\
(0.0)\end{array}$ \\
\hline
\end{tabular}

An enquiry on the perceived air quality was given in the questionnaire and it should be noted that only the $\mathrm{CO}_{2}$ data are presented in this study. Out of the 36 votes collected, 29 were placed on the cleaner side of the air quality scale and none of the respondents felt that their office was dusty or detected any foul-smelling odour. With a total mean air quality score of 1.56, it shows that the occupants were generally contented with the IAQ in the offices.

\subsection{PMV, AMV and neutral temperature}

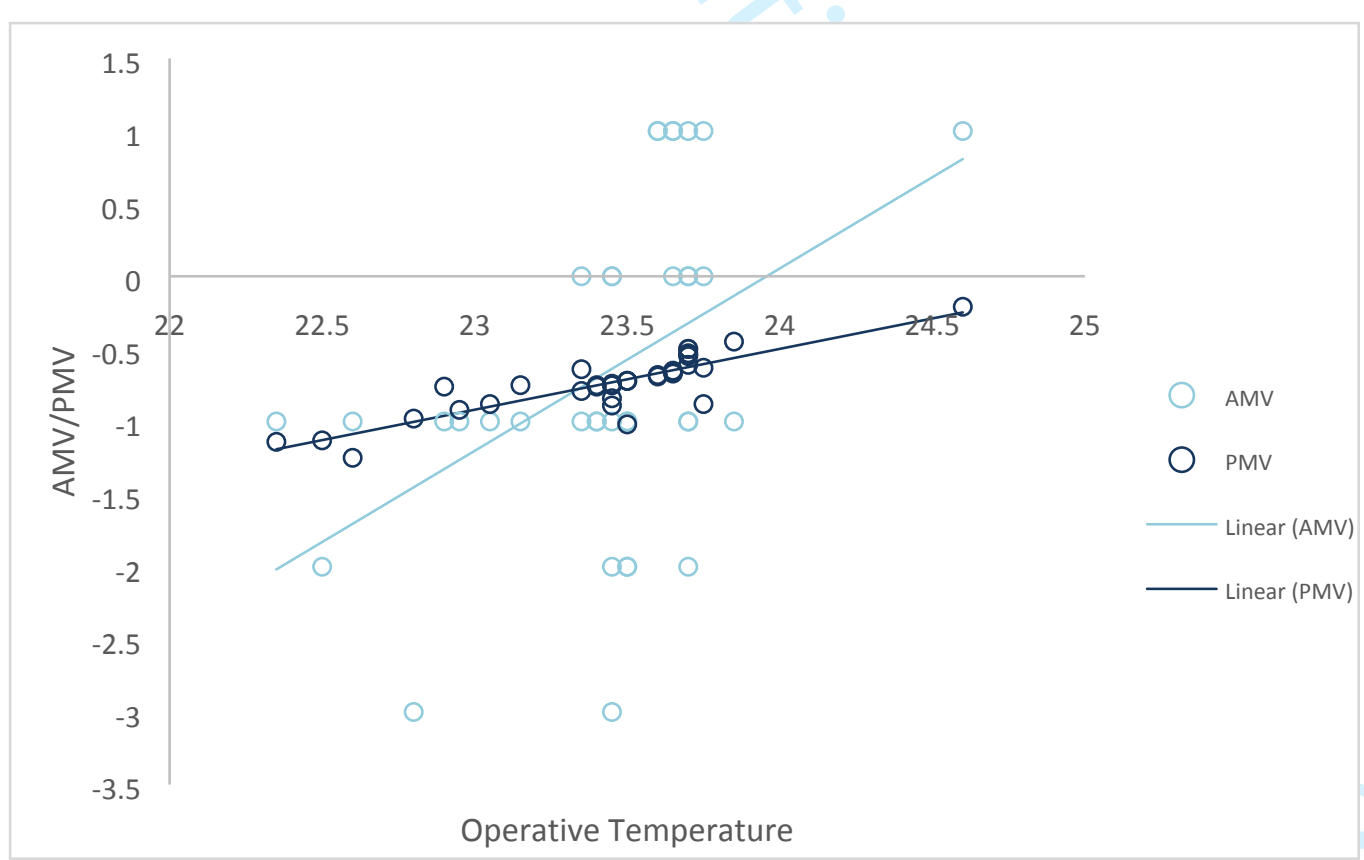

Figure 3: Thermal neutrality in the offices

The AMV of the occupants was determined using the field data collected. The relationship between operative temperature, PMV and AMV was analysed and the outcome is presented in Figure 3. Using the linear equation derived, the thermal neutrality equation based on the AMV is as follows:

$T_{o p}=(A M V+30.086) / 1.2558$ 
where $T_{o p}$ is the operative temperature.

The neutral temperature for all three office areas was $23.96^{\circ} \mathrm{C}$ and the comfortable temperatures (for AMV within -0.5 to +0.5 ) ranged from 21.90 to $24.46^{\circ} \mathrm{C}$. However, it was found that the predicted thermal neutrality was $25.19^{\circ} \mathrm{C}$, which is $1.23^{\circ} \mathrm{C}$ higher than the actual thermal sensation. From the illustrations, it can be observed that the academic room has the least deviation between AMV and PMV values where a difference of $1.12^{\circ} \mathrm{C}$ was found.

\subsection{Air change rate and air quality level}

Another attempt of this study was to measure the supply air movement rate from the diffusers for $I A Q$ evaluation. Using an anemometer with mini vane probe, the supply air velocity at the diffusers of each office space was systematically measured. The data obtained are presented in Table 6. Higher mean supply air velocities were recorded at the reception area, which was designed to be a common area where visitors and students gathered. At other locations, the range of average air movement was generally within 0.86 (169 FPM) to $5.57 \mathrm{~m} / \mathrm{s}$ (1,096 FPM). Multiplied with the area factor of the rectangular duct, the airflow rates of the diffusers were calculated and found to be from 0.08 to 0.73 $\mathrm{m}^{3} / \mathrm{s}$ (about 170 to 1,547 CFM) at the more enclosed administrative and academic rooms, while the volumetric airflow at the reception area was from 2.90 to $5.41 \mathrm{~m}^{3} / \mathrm{s}$ (about 6,145 to $11,463 \mathrm{CFM}$ ). The mean air change per hour (ACH) of the reception area, administrative and academic offices were therefore calculated as $6.7 \mathrm{ACH}, 4.5 \mathrm{ACH}$ and $6.2 \mathrm{ACH}$ respectively. Using the design occupation density for offices (CIBSE, 2008), the ventilation rate per person was estimated. It was found that the air supply rates per person were higher than the $10{\mathrm{~L} . \mathrm{s}^{-1}}^{-1}$ per person suggested by the standard except for the administrative office, where a mean flowrate of 9.4 L.s.-1 per person was calculated.

Table 6: Mean values of supply air velocity at diffusers

\begin{tabular}{|c|c|c|c|c|c|c|c|}
\hline \multirow[t]{2}{*}{ Location } & \multirow{2}{*}{$\begin{array}{l}\text { Diffuser } \\
\text { No. }\end{array}$} & \multicolumn{4}{|c|}{ Mean Air Velocity $(\mathrm{m} / \mathrm{s})$} & \multirow{2}{*}{$\begin{array}{l}\text { Estimated range of } \\
\text { airflow rate }\left(\mathrm{m}^{3} / \mathrm{s}\right)\end{array}$} & \multirow{2}{*}{$\begin{array}{l}\text { L.s. }{ }^{-1} \text { per } \\
\text { person }\end{array}$} \\
\hline & & Point 1 & Point 2 & Point 3 & Point 4 & & \\
\hline Reception area & SAA1 & 4.3 & 2.3 & - & - & $3.36-7.72$ & 51.0 \\
\hline \multirow{4}{*}{$\begin{array}{l}\text { Administrative } \\
\text { office }\end{array}$} & SAB1 & 0.9 & 1.0 & 0.7 & 0.9 & $0.07-0.14$ & \multirow[t]{4}{*}{9.4} \\
\hline & SAB2 & 0.9 & 1.2 & 1.3 & 1.3 & $0.09-0.20$ & \\
\hline & SAB3 & 1.0 & 0.9 & 0.9 & 1.0 & $0.10-0.17$ & \\
\hline & SAB4 & 2.5 & 1.1 & 0.7 & 1.9 & $0.08-0.38$ & \\
\hline \multirow{3}{*}{$\begin{array}{l}\text { Academic } \\
\text { room }\end{array}$} & SAC1 & 0.9 & 3.7 & 1.4 & 1.1 & $0.13-0.53$ & \multirow[t]{3}{*}{22.5} \\
\hline & SAC2 & 5.6 & 1.5 & 1.2 & 3.4 & $0.13-0.73$ & \\
\hline & SAC3 & 1.5 & 1.7 & 1.4 & 1.5 & $0.13-0.23$ & \\
\hline
\end{tabular}

This study also analysed the room air quality by monitoring the carbon dioxide levels within selected office compounds. $\mathrm{CO}_{2}$ concentration levels at the air diffuser outlets, at table level $0.75 \mathrm{~m}$ above floor) and at the inlets of return grilles of the academic and administrative offices were measured using a portable $\mathrm{CO} / \mathrm{CO}_{2}$ gases monitor. As for the reception area, only the $\mathrm{CO}_{2}$ level of the supply air was measured. Table 7 presents the mean $\mathrm{CO}_{2}$ level at each office location. The mean $\mathrm{CO}_{2}$ levels were found to be within 633 to $884 \mathrm{ppm}$. The highest mean concentration was measured at the exhaust air grilles of the administrative office, whereas the return air at the academic room were measured with 
$728 \mathrm{ppm}$ of $\mathrm{CO}_{2}$. The mean concentrations of $\mathrm{CO}_{2}$ at the supply air diffusers were lower at $707 \mathrm{ppm}$, while the table level had the lowest concentration at which an average concentration of $687 \mathrm{ppm}$ was recorded.

Table 7: Mean $\mathrm{CO}_{2}$ concentration level (ppm)

\begin{tabular}{lcccc}
\hline Location & \multicolumn{4}{c}{$\mathrm{CO}_{2}$ level (ppm) } \\
\cline { 2 - 5 } & Point 1 & Point 2 & Point 3 & Point 4 \\
\hline Reception area & & & & \\
Supply air (SAA1) & 634 & 648 & 656 & - \\
Administrative office & & & & \\
Supply air (SAB1) & 727 & 735 & 743 & 668 \\
Table level & 677 & 707 & 708 & 651 \\
Return air & 884 & 873 & 735 & - \\
& & & & \\
Academic room & & & & \\
Supply air (SAC1) & 731 & 735 & 716 & 780 \\
Table level & 666 & 723 & 678 & 683 \\
Return air & 684 & 664 & 803 & 759 \\
\hline
\end{tabular}

\section{Discussion}

\subsection{Field survey outcomes}

The thermal comfort parameters at the three locations studied were systematically measured, following the recommendations of ASHRAE Standard 55 (2017). The datalogger was positioned as near to the survey respondents as possible. There were times when the air movement was not detected at the measuring height of $0.6 \mathrm{~m}$ even though air was actually supplied through the diffusers, especially at the reception area. This was mostly owing to the direction of supply air flow from the ceiling diffusers, which were designed to be right at the top of the front office desk and the air flow was directed towards the customer seats. Although the mean PMV index showed that the region was within the "slightly cool" category thanks to the low air and radiant temperatures, the use of portable standing fans can be considered when there was no noticeable air movement during office hours to avoid air stagnation.

From the POE outcomes, it can be observed that the 7 votes placed on the "slightly warm" category of the thermal sensation scale were from the reception area and academic room. One of the obvious reasons for this was that about half of the survey respondents were seated at locations near to the windows and their sensations were recorded during the warmer time (around 1300 to $1500 \mathrm{hrs}$ ) of the day. The type of façade system and shading devices used in these spaces may have contributed to this result, as it was found that the type of shading could potentially affect thermal comfort and space cooling capacity (Udrea and Badescu, 2020). However, a contradicting result was obtained at which most of the occupants seated at this location found their thermal environment acceptable because they voted within the three central ratings $(-1,0,+1)$. While efforts were made to minimize the influence of non-thermal parameters in affecting the reliability of the survey outcomes, factors such as individual preference for a cooler environment, clothing level and their prior thermal experience could have also contributed to this outcome. It was proposed in the work of Langevin et al. (2015) that behavioural models should be developed to characterise inter-individual variations in thermal 
behaviour, which will be among the considerations for future studies. The survey findings also proposed that most of the occupants had at least somewhat adapted to their thermal surroundings. A slightly lower adaptation rate was identified at the reception area, which was found to have a lower mean air velocity. Among the reasons for this was that this space was open to the public and near to the building entrance, where variations in thermal environment could possibly happened due to the frequent opening of the glass door, especially during peak working hours for workers and office goods flow. The large glazing area at this location may be another important factor.

In general, the high percentage of votes placed within the slightly warm (+1) and slightly cool $(-1)$ sensations showed that most of the occupants were thermally comfortable. This outcome revealed that the green campus was well designed, maintained and operated to ensure a good indoor surrounding is provided to the users. Considering the $80 \%$ thermal adaptation level and the total sensation votes which skewed towards the cooler part of the scale, an energy efficiency improvement opportunity has been identified where higher temperature set-points can be considered. As for the occupant thermal preference, a significant number of the subjects preferred cooler environments although they were already feeling comfortable. Such "need more cooling" sensation phenomenon had also been reported in several previous studies carried out in the hot-humid region (He et al., 2016; Lu et al., 2018; Azizpour et al., 2013), which suggested that people residing in this region has a natural tendency of wanting a cooler indoor environment because of the hot and humid weather outside even though they are usually more tolerant to the warmer thermal environment.

\subsection{Thermal neutrality, AMV and PMV}

A comparison was made between the calculated AMV and PMV. It was found that the difference between these two indices was 0.12 for the studied areas. Unlike the findings reported in naturally aired buildings where large deviations between PMV and mean TSV were found (Li et al, 2018), the small differences in this study are mostly attributed to the fact that the spaces were air-conditioned and the return air temperature was set within the stipulated comfort range. Similar outcome was reported in a field study, where a strong linear relationship between the mean sensation vote and PMV was obtained in air-conditioned classrooms (Zhao et al., 2018). Furthermore, in order to reduce any inaccuracies in the survey data, it was sought to invite only the respondents who had been seated for more than 15 minutes to join the survey as they were considered to be already adapted to their thermal surroundings (ASHRAE, 2017). This is also to prevent any form of abrupt change in the occupants' thermal experience, for instance, workers who have just entered the air-conditioned office after returning from outdoor activities may have a very different thermal sensation than their more sedentary colleagues.

\subsection{Air distribution and IAQ}

Installed with the rectangular flush mount ceiling diffusers, the supply air flow rate at the reception area was higher than other office spaces cooled via standard ceiling square diffusers. This was because of the required supply air volume for the larger space area and estimated occupancy rate. The calculated air supply rate per person for the three areas were much higher than the typical ventilation requirement of 10 L.s $^{-1}$ per person, which revealed that the airflow rates were sufficient in providing a comfortable indoor environment. The high airflow rates per person at the reception area was due to the larger space area and height of the building space (about 5 meters), and the air flowrate was adjusted based on the air-change requirement. As for the administrative office, the supply air rate per 
person was slightly lower than the suggested value because the density of occupation was higher than the benchmark value of 1 person per $\mathrm{m}^{2}$. Anyway, the $\mathrm{ACH}$ was sufficient and within the acceptable range of 4-6 ACH for office areas (CIBSE, 2008). Throughout this survey, the positive mean score of the air quality scale proposed that the offices were very well managed and the centralised airconditioning system was functioning efficiently to maintain acceptable air quality.

From the sampling points measured, it was found that the $\mathrm{CO}_{2}$ level measured at the table level was within $634-750 \mathrm{ppm}$. This shows that the air quality in the commonly occupied rooms was acceptable as the $\mathrm{CO}_{2}$ concentrations were below the ceiling limit of ventilation performance indicator of $1000 \mathrm{ppm}$ specified in the local indoor air standard (DOSH, 2010). The rate of fresh air intake volume can be increased during high occupancy time to ensure that the air quality is always good. Previous studies have proposed the use of more indoor plants (Smith et al., 2017) and active green walls (Torpy et al., 2017) as they help in reducing the $\mathrm{CO}_{2}$ level in enclosed offices. More dehumidification of the air intake should also be made since the mean $\mathrm{RH}$ values at the academic room were slightly higher than $70 \%$. These measures are particularly important to further improve the IAQ condition which is essential to ensure the well-being and productivity of the occupants.

As only the open-plan office areas were considered in this case study, further work which focused on thermal comfort at other occupied spaces in the campus, such as the testing facilities and learning areas is needed to obtain a larger sampling size for better descriptions of thermal comfort and IAQ. The perceptions of occupants other than the full-time staff can be studied. Data can be taken at different height levels to check if standing occupants would experience different thermal sensation than those who are seated. The measurement of other indoor air contaminants, for instance the particulate matters and volatile organic compounds' concentrations is equally essential to allow a better understanding of the actual office air quality level.

\section{Conclusion}

Many thermal comfort and IAQ works using POE have been carried out in different building types under different climatic conditions. In this study, a POE was carried out to identify the thermal comfort and air quality conditions together with the accompanying occupant reception in a green-rated campus building where the climate is hot and humid. The research outcomes are summarised as follows:

i) Instrumental measurements revealed that the thermal comfort parameters were within the acceptable ranges stipulated in the local IAQ guideline. This has proposed that all the three locations studied were well maintained by the building operator. The measured supply air rates presented that the office spaces were adequately ventilated. The $\mathrm{CO}_{2}$ concentrations in the offices were also controlled below the gaseous threshold limit to ensure good IAQ.

ii) From the survey findings, a majority of the TSV was placed on the three central categories and most of the test subjects preferred no changes to be made on their thermal surroundings. However, the preference for more cooling was signified by some of the occupants although they were thermally comfortable at present. This study further highlights that the thermal sensation was affected by the air movement, where warmer sensations would be experienced if there is air stillness even if the air temperature and 
$\mathrm{RH}$ are within acceptable ranges. No poor rating was received for the air quality scale, which demonstrated the air freshness level was acceptable for the occupants.

iii) Small variations between AMV and PMV were identified in this study as the office spaces under consideration were mechanically cooled with the temperature settings within the comfortable range. The comparison of $\mathrm{AMV}$ and PMV with the operative temperature values showed that the former indicated a lower thermal neutrality than the latter. This can be largely owing to the thermal experience and personal fondness for a lower surrounding temperature among the survey respondents, which had been reported in the questionnaire survey.

iv) Although the volumetric flowrate was sufficient, there is a need for a higher air velocity, coupled with more fresh air supply especially in areas with high occupancy rates to dilute the air contaminant's concentration. Resetting the return air temperature to be 1 to $2{ }^{\circ} \mathrm{C}$ higher can be made as the neutral temperature of the office areas was found to be lower than the current temperature settings. This is particularly important to reduce energy use, which could partially offset the energy needed for the higher fresh air intake rate.

\section{References}

American Society of Heating, Refrigerating and Air-Conditioning Engineers (ASHRAE) (2017). Standard 55 - Thermal environmental conditions for human occupancy, Atlanta, GA. ISSN 1041 -2336

Azizpour, F., Moghimi, S., Lim, C.H., Mat, S., Salleh, E., Sopian, K. (2013). Thermal comfort investigation of a facility department of a hospital in hot-humid climate: Correlation between objective and subjective measurements. Indoor and Built Environment, Vol. 22, 836 - 845. Doi: $0.1177 / 1420326 \times 12460067$

Bunn, R., Marjanovic-Halburd, L. (2017). Comfort signatures: How long-term studies of occupant satisfaction in office buildings reveal on-going performance, Building Services Engineering Research and Technology, Vol. 38 (6), 663 - 690. Doi: 10.1177/0143624417707668

Clements-Croome, D. (2001). Creating the Productive Workplace, E \& FN Spon, Taylor and Francis Group, London, Great Britain. ISBN 0-203-02781-7

Deuble, M.P., de Dear, R.J. (2014). Is it hot in here or is it just me? Validating the post-occupancy evaluation, Intelligent Buildings International, Vol. 6 (2), 112 - 134. Doi: http://dx.doi.org/10.1080/17508975.2014.883299

DOSH (2010). Industry Code of Practice on Indoor Air Quality 2010, Department of Occupational Safety and Health, Ministry of Human Resources, Malaysia. JKKP DP (S) 127/379/4-39.

Driza, P.J.N., and Park, N.K. (2014). Occupant satisfaction in LEED-certified higher education buildings, Smart and Sustainable Built Environment, Vol. 3 (3), 223-236. Doi: 10.1108/SASBE-02-2014-0013

El-Darwish, I.I., El-Gendy, R.A. (2018). Post occupancy evaluation of thermal comfort in higher educational buildings in a hot arid climate, Alexandria Engineering Journal, Vol. 57 (4), $3167-3177$. Doi: https://doi.org/10.1016/j.aej.2017.11.008 
Fang, Z., Zhang, S., Cheng, Y., Fong, A.M.L., Oladokun, M.O., Lin, Z., Wu, H. (2018). Field study on adaptive thermal comfort in typical air conditioned classroom, Building and Environment, Vol. 133, 73 - 82. Doi: https://doi.org/10.1016/j.buildenv.2018.02.005

Gallardo, A., Palme, M., Lobato-Cordero, A., Beltran, R.D., Gaona, G. (2016). Evaluating thermal comfort in a naturally conditioned office in a temperate climate zone, Buildings, Vol. 6, 27. Doi: 10.3390 /buildings 6030027

Gutierrez-Aliaga, L., Williams, E. (2016). Co-alignment of comfort and energy saving objectives for U.S. office buildings and restaurants, Sustainable Cities and Society, Vol. 27, 32 - 41. Doi: https://dx.doi.org/10.1016/j.scs.2016.08.010

He, Y., Li, N., Peng, J., Zhang, W., Li, Y. (2016). Field study on adaptive comfort in air conditioned dormitories of university with hot-humid climate in summer, Energy and Buildings, Vol. 119, $1-12$. Doi: http://dx.doi.org/10.1016/j.enbuild.2016.03.020

Hwang, T., Kim, J.T. (2013). Assessment of indoor environmental quality in open-plan offices, Indoor and Built Environment, Vol. 22 (1), 139 - 156. Doi: 10.1177/1420326X12470280

Kamaruzzaman, S.N. and Azmal, A.M. (2019), "Evaluation of occupants' well-being and perception towards indoor environmental quality in Malaysia affordable housing", Journal of Facilities Management, Vol. 17 No. 1, pp. 90-106. Doi: https://doi.org/10.1108/JFM-11-2017-0070

Khajehzadeh, I. and Vale, B. (2016), "Shared student residential space: a post occupancy evaluation", Journal of Facilities Management, Vol. 14 No. 2, pp. 102-124. Doi: https://doi.org/10.1108/JFM-092014-0031

Kramer, R., Schellen, L., Schellen, H. (2018). Adaptive temperature limits for air-conditioned museums in temperate climates, Building Research and Information, Vol. 46 (6), 686 - 698. Doi: https://doi/full/10.1080/09613218.2017.1327561

Lakeridou, M., Ucci, M., Marmot, A., Ridley (2012). The potential of increasing cooling set-points in air-conditioned offices in the UK, Applied Energy, Vol. 94, 338 - 348. Doi: http://dx.doi.org/10.1016/j.apenergy.2012.01.064

Langevin, J., Gurian, P.L., Wen, J. (2015). Tracking the human-building interaction: A longitudinal field study of occupant behaviour in air-conditioned offices. Journal of Environmental Psychology, Vol. 42, 94 - 115. Doi: http://dx.doi.org/10.1016/i.jenvp.2015.01.007

Lau, H. Personal Communication. 25 September 2020.

Li, B., Du, C., Yao, R., Yu, W., Costanzo, V. (2018). Indoor thermal environments in Chinese residential buildings responding to the diversity f climates, Applied Thermal Engineering, Vol. 129, 693 - 708. Doi: https://doi.org/10.1016/j.applthermaleng.2017.10.072

Lu, S., Pang, B., Qi, Y. Fang, K. (2018). Field study of thermal comfort in non-air-conditioned buildings in a tropical island climate, Applied Ergonomics, Vol. 66, 89 - 97. Doi: http://dx.doi.org/10.1016/j.apergo.2017.08.008 
Mahyuddin, N., Awbi, H.B., Alshitawi, M. (2014). The spatial distribution of carbon dioxide in rooms with particular application to classrooms, Building Services Engineering Research and Technology, Vol. 23, No. 3, 433 - 448. Doi: 10.1177/1420326X13512142

Marques, G., Ferreira, C.R., Pitarma, R. (2019). Indoor Air Quality Assessment Using a CO2 Monitoring System Based on Internet of Things, Journal of Medical Systems, Vol. 43, 67. Doi: https://doi.org/10.1007/s10916-019-1184-x

Meir, I.A., Garb, Y., Jiao, D., Cicelsky, A. (2009). Post-occupancy evaluation: An inevitable step toward sustainability, Advances in Building Energy Research, Vol. 3, 189 - 220. Doi: 10.3763/aber.2009.0307

Mihai, T., lordache, V. (2016). Determining the indoor environment quality for an educational building. Energy Procedia, Vol. 85, 566 - 574. Doi: 10.1016/j.egypro.2015.12.246

Rijal, H.B., Humphreys, M., Nicol, F. (2015). Adaptive thermal comfort in Japanese houses during the summer season: Behavioural adaptation and the effect of humidity. Buildings, Vol. 5, $1037-1054$. Doi: 10.3390/buildings5031037

Roskams, M. and Haynes, B. (2019), "Predictive analytics in facilities management: A pilot study for predicting environmental comfort using wireless sensors", Journal of Facilities Management, Vol. 17 No. 4, pp. 356-370. https://doi.org/10.1108/JFM-03-2019-0008

Sant'Anna, D.O., Dos Santos, P.H., Vianna, N.S., Romero, M.A. (2018). Indoor environmental quality perception and users' satisfaction of conventional and green buildings in Brazil. Sustainable Cities and Society, Vol. 43, 95 - 110. Doi: https://doi.org/10.1016/j.scs.2018.08.027

Shahzad, S.S., Brennan, J., Theodossopoulos, D., Hughes, B., Calautit, J.K. (2016). Building-related symptoms, energy, and thermal control in the workplace: Personal and open plan offices. Sustainability, Vol. 8, 331. Doi: 10.3390/su8040331

Smith, A., Fsadni, A., Holt, G. (2017). Indoor living plants' effects on an office environment. Facilities, Vol. 35 (9/10), 525 - 542. Doi: https://doi.org/10.1108/F-09-2016-0088

The Chartered Institution of Building Services Engineers, CIBSE (2008). CIBSE Concise Handbook, The Chartered Institution of Building Services Engineers, London, Great Britain. ISBN 978-1-903287-94-1

Torpy, F., Zavattaro, M., Irga, P. (2017). Green wall technology for the phytoremediation of indoor air: a system for the reduction of high $\mathrm{CO} 2$ concentrations, Air Quality, Atmosphere and Health, Vol. 10, 575-585. Doi: https://doi.org/10.1007/s11869-016-0452-x

Toyin Sawyerr, P. and Yusof, N. (2013), "Student satisfaction with hostel facilities in Nigerian polytechnics", Journal of Facilities Management, Vol. 11 No. 4, pp. 306-322. Doi: https://doi.org/10.1108/JFM-08-2012-0041

Udrea, I., Badescu, V. (2020). Usage of solar shading devices to improve the thermal comfort in summer in a Romanian PassivHaus, Simulation: Transactions of the Society for Modeling and Simulation Internation, Vol. 96 (5), 471 - 486. Doi: 10.1177/0037549719887790 
Wang, X., Altan, H., Kang, J. (2015). Parametric study on the performance of green residential buildings in China, Frontiers in Architectural Research, Vol 4 (1), 56 - 67. Doi: https://doi.org/10.1016/j.foar.2014.06.007 